\title{
The tobacco industry and Aboriginal and Torres Strait Islander people
}

\section{A systematic search at the source of the smoking problem}

hile there has been a redoubling of efforts to reduce smoking rates among Indigenous Australians, Indigenous health researchers have paid almost no attention to the tobacco industry - the "vector" of smoking-related diseases. The exceptions are two reports of the use of Aboriginal images to advertise Winfield cigarettes in Europe. ${ }^{1,2}$ We decided to examine industry documents to look for the inside story of the tobacco industry's approach to the Indigenous Australian market.

\section{Methods, sources and their limitations}

The online Legacy Tobacco Documents Library (LTDL) has more than 70 million pages of tobacco industry documents, of which $98 \%$ are full-text and searchable. ${ }^{3}$ Most of these records relate to the 1998 Master Settlement Agreement (MSA), which continues to require transnational tobacco companies operating in the United States to make publicly available all industry documents disclosed during the pre-trial "discovery" phase of past and future lawsuits. The LTDL does not include all Australian industry documents, but can still be used to investigate the attention paid to Australia by transnational tobacco companies. ${ }^{4,5}$ The completeness of the collection is further compromised by the industry's destruction of many documents; ${ }^{4}$ nevertheless, some consistent themes emerge.

We searched the LTDL for tobacco industry references to Aboriginal and Torres Strait Islander people, guided by standard procedures. ${ }^{6}$ Initial keyword search terms were "Australia" or "Australian" combined with "Indigenous", "Aboriginal", "Aborigine" or "Torres Strait Islander". Further search terms were from items discussed in the two previously published articles ${ }^{1,2}$ or from items in the documents retrieved in the primary search. These included "Kata Tjuta", "Get your own black" and combinations of: "Winfield", "peace pipe" and "Think Downunder"; "Olgas" and "Australia"; and "Senate", "Australia" and "Aboriginal". The document searching was conducted between December 2010 and September 2011. A total of 2295 documents were reviewed. We also investigated newspaper and parliamentary reports referred to in the industry documents. We reviewed all documents to assess whether they included evidence about the industry's approach to the Indigenous market. Most did not. Those that did were analysed for emergent themes.

\section{Tobacco industry monitoring}

Transnational tobacco companies routinely monitor Australian media, parliamentary and scientific reports,
David P Thomas MB BS, PhD, FAFPHM Principal Research Fellow

Laura Bond Policy Officer ${ }^{2}$

1 Menzies School of Health Research and the Lowitja Institute, Charles Darwin University, Darwin, NT.

2 Public Health Division, Western Australia Department of Health.

david.thomas@ menzies.edu.au

doi: $10.5694 / \mathrm{mjall} .11275$

In 1984, the Sydney Morning Herald reported that the National Aboriginal Conference (NAC), an elected Aboriginal organisation, had brought a claim against WD \& HO Wills that an advertisement for John Player Special cigarettes was racist. The advertisement included the text "Get your own black" (Box), an allusion to owning black
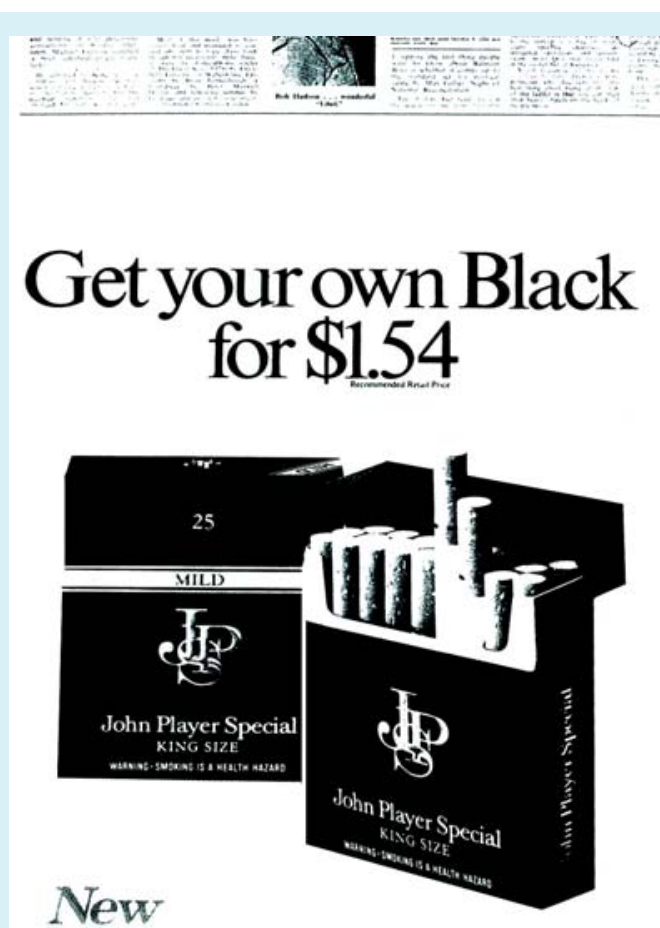

John Player Special King Size 25s

Some things in life have a special quality.

The offensive advertisement for John Player Special Cigarettes, which was withdrawn after successful action by the National Aboriginal Conference (NAC) in 1984. 
servants, although ostensibly referring to the black branding. 7,8 The tobacco company was forced to withdraw the offensive advertisement - a resounding victory for the NAC on behalf of Aboriginal people.

In 1998, the same newspaper described the use of several Australian icons, including Aboriginal imagery, to promote Winfield cigarettes in Europe. ${ }^{1,9}$ One billboard showed an Aboriginal man playing a didgeridoo and included, in German, the slogan "Australians' answer to the peace pipe". The company's spokesperson said the advertisements were justified, as Winfield was itself an iconic Australian brand. She did not comment on the Aboriginal images, but Aboriginal spokespeople from the National Aboriginal Community Controlled Health Organisation and the Australian Medical Association called them demeaning misrepresentations.

Te Reo Marama, a Maori tobacco-control organisation in New Zealand, has also complained about the use of Indigenous imagery to market cigarettes, and has celebrated the more recent withdrawal of brands in response to its complaints. ${ }^{10}$

\section{Targeting Aboriginal and Torres Strait Islander people}

The Australian Government Senate Community Affairs References Committee held an inquiry into "The Tobacco Industry and the Costs of Tobacco-related Illness" in 19941995. ${ }^{11}$ The internal memos and public statements by the industry that were related to this inquiry contain the most detailed evidence available of the industry's approach to Aboriginal and Torres Strait Islander people. The report's final chapter included a section about smoking among Indigenous people and three recommendations (out of 39) that called for more attention and funding for tobacco control in Indigenous communities.

The industry seemed little concerned with this focus on Indigenous tobacco control. Companies did not mention Indigenous people in their briefings before and after hearings, or in their press releases that attacked the report. ${ }^{12-14}$ Philip Morris's detailed response to the report did not oppose the recommendations regarding Indigenous people. ${ }^{15}$ It is not clear why the industry chose not to oppose targeted campaigns to reduce smoking among Indigenous people. Was it just strategic spin, to appear reasonable on many issues and just oppose those that would have the greatest impact on profits (those reducing consumption in the entire population)? Was it because the industry believed, as does Chapman, ${ }^{16}$ that targeted campaigns lead to inefficiencies and fragmentation of limited budgets? Tobacco-control programs targeting Indigenous people were just a vague promise in 1995, but now more than $\$ 100$ million has been allocated to Indigenous anti-tobacco measures. ${ }^{17}$ Yet we have seen no industry response to this large new investment.

The Senate inquiry also pointed to possible targeting of Aboriginal people by the tobacco industry. The Northern Territory Department of Health and Community Services' submission described a Philip Morris promotion that provided a T-shirt with the purchase of two packs of Marlboro cigarettes in Aboriginal communities. ${ }^{11}$ In some cases, the name of the community was included on the T-shirt in the Marlboro colours and design, but the company insisted this was only with the agreement of the local community. Philip Morris responded that the "promotion was similar to other promotions throughout the country" and denied any "unscrupulous targeting". This can possibly be believed, as a later internal industry briefing emphasised protecting these types of promotions used in all settings, which the Committee had recommended be banned, more than defending itself against claims of targeting a vulnerable population. ${ }^{11,18}$

There is no evidence in the industry documents to suggest there was a separate tobacco industry campaign targeting Aboriginal and Torres Strait Islander communities and smokers. The same approach appears to have been used as elsewhere in Australia, perhaps with some nuances that were not identified because of the limitations of these transnational industry documents. In contrast, in the larger American market the industry did mount campaigns targeting the large African-American community. ${ }^{19}$ The industry may perceive the Indigenous section of the Australian market as too small $(<2 \%$ of the population aged $15+)^{20}$ to warrant targeting.

\section{Conclusion}

These industry stories can be used in discussions about smoking with Aboriginal and Torres Strait Islander people. They can shift discussion from "blaming the victim" to starting to understand the industry that profits from this product that causes so much illness, death and misery an industry represented by such statements as the notorious comment attributed to an RJ Reynolds Tobacco Company executive: "We don't smoke the shit, we just sell it. We reserve the right to smoke for the young, the poor, the black and the stupid". 21

Acknowledgements: David Thomas is supported by a National Heart Foundation Career Development Award Fellowship. Maria Halkitis assisted with locating newspaper articles.

Competing interests: No relevant disclosures.

Provenance: Not commissioned; externally peer reviewed.

1 Chapman S. The ugly Australian from Rothmans, in Germany. Tob Control 1999; 8: 362-363.

2 Butler R, Chapman S, Thomas DP, Torzillo P. Low daily smoking estimates derived from sales monitored tobacco use in six remote predominantly Aboriginal communities. Aust N Z J Public Health 2010; 34 Suppl 1: S71-S75.

3 Legacy tobacco documents library [internet]. San Francisco (CA): Regents of the University of California. http://legacy.library.ucsf.edu/ (accessed Sep 2011).

4 Chapman S, Byrne F, Carter SM. "Australia is one of the darkest markets in the world": the global importance of Australian tobacco control. Tob Control 2003; 12 Suppl 3: iiil-3.

5 Stafford J, Bond L, Daube M. "We are still not yet out of the woods in WA": Western Australia and the international tobacco industry. Perth: WA Tobacco Document Searching Program, Curtin University of Technology, 2009. healthsciences.curtin.edu.au/watdsp/local/docs/watdsp_monograph.pdf (accessed Feb 2012).

6 Hirschhorn N. The Tobacco Industry documents: what they are, what they tell us, and how to search them. A practical manual. Geneva: World Health Organization, 2005. http://www.who.int/tobacco/communications/TI manual_content.pdf (accessed Sep 2011).

7 NAC complaints get cigarette ad dropped. Sydney Morning Herald 1984; 3 Aug: 4.

8 BATCo additional supplementary press cuttings: index. 14 Aug 1984. British American Tobacco. Bates No. 105651923. http://legacy.library.ucsf.edu/tid/ pmc77a99 (accessed Sep 2011). 
9 Sweet M. Anyhow, have a digeridoo: our smoking image abroad. Sydney Morning Herald 1998; 2 Jul: 1,8.

10 Te Reo Marama. Success stories. http://www.tereomarama.co.nz/Site/media/ media.aspx (accessed Sep 2011).

11 Senate Community Affairs References Committee. The tobacco industry and the costs of tobacco-related illness. Canberra: Commonwealth of Australia, 1995. http://www.aph.gov.au/Parliamentary_Business/Committees/Senate_ Committees?url=clac_ctte/completed_inquiries/prel996.htm (accessed Feb 2012).

12 Riordan M. Senate communications discussion paper [memo]. 20 Jan 1994. British American Tobacco. Bates No. 502594420-502594422. http:// legacy.library.ucsf.edu/tid/rll43a99 (accessed Sep 2011).

13 Davies D, Hill J. Weekly report - Australia [memo]. 24 Feb 1995. Philip Morris. Bates No. 2045745612/5614. http://legacy.library.ucsf.edu/tid/uoz74a00 (accessed Sep 2011).

14 Weir MA. Senate inquiry [memo with press releases and minority report]. 15 Dec 1995. British American Tobacco. Bates No. 800190658-800190689. http:/ /legacy.library.ucsf.edu/tid/lsb8la99 (accessed Sep 2011).

15 Philip Morris. Response to "The tobacco industry and the costs of tobaccorelated illness" report of the Senate Community Affairs References Committee. June 1996. Philip Morris. Bates No. 2073934821/2073934958. http:// legacy.library.ucsf.edu/tid/bqx42c00 (accessed Sep 2011).
16 Chapman S. Public health advocacy and tobacco control: making smoking history. Oxford: Blackwell Publishing, 2007.

17 Roxon N, Snowdon W. Break the chain: Indigenous anti tobacco campaign kicks off [media release]. 28 March 2011. http://www.health.gov.au/internet/ ministers/publishing.nsf/Content/510DC8E17ED3B784CA25786100142253/ \$File/nr053.pdf (accessed Apr 2011).

18 Industry Issues. 2 Oct 1996. Philip Morris. Bates No. 2504081799/1923. http:// legacy.library.ucsf.edu/tid/vwy45d00 (accessed Sep 2011).

19 Tobacco use among US racial/ethnic minority groups: a report of the Surgeon General. Washington, DC: US Department of Health and Human Services, 1998. http://www.cdc.gov/tobacco/data_statistics/sgr/1998/complete_ report/pdfs/complete_report.pdf (accessed Feb 2012).

20 Australian Bureau of Statistics. Population characteristics, Aboriginal and Torres Strait Islander Australians, 2006. Reissue. Canberra: ABS, 2010. (ABS Cat. No. 4713.0.) http://www.ausstats.abs.gov.au/ausstats/subscriber.nsf/0/ 526FE126443EBCC6CA257718001D547F/\$File/47130_2006_reissue.pdf (accessed Feb 2012).

21 Tobacco.org. Tobacco wars: TLC and BBC News present the definitive story of "big tobacco", told by insiders from the cigarette industry, medicine, marketing and politics. http://www.tobacco.org/News/9910tobaccowars.html (accessed Mar 2012).

\section{Stamps of greatness}

\section{Wilhelm Conrad Roentgen (1845-1923)}

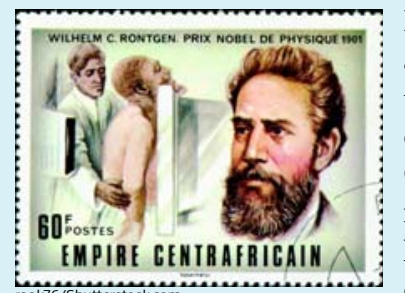

ROENTGEN was born in Lennep (now a borough of the city Remscheid) in the Lower Rhine province of Germany on 27 March 1845, the child of a German cloth merchant and a Dutch mother. His parents moved to the Netherlands when he was a young child, and he was educated in Utrecht.

Being a dreamer and hating routine and standardisation, he was a mediocre student until he came under the influence of Clausius at the Federal Polytechnic Institute in Zurich. Clausius was also the teacher of Willard Gibbs, later professor of mathematical physics at Yale. Roentgen received his doctorate in physics from the University of Zurich in 1869.

After teaching in Strasbourg, Hohenheim and Giessen, he became professor of physics at the University of Wurzburg (in 1888) and then at the University of Munich (in 1900). There, on 8 November 1895 , while experimenting with a Crookes tube with reference to Hittorf (cathode) and Lenard rays, Roentgen noticed that this produced strange shadows of solid objects. By making his tube lightproof, a greenish fluorescent light could be thrown on a platino-barium screen 9 feet away - a new kind of radiation. These rays passed through most substances, the soft parts of the body in particular, so that the bones on his hand, being denser, were boldly revealed on a photographic plate.

This discovery was first reported in his classical preliminary communication to the president of the Physical Medical Society of Wurzburg on 28 December 1895 . Roentgen modestly called the new rays $\mathrm{x}$-rays, but on the motion of Kolliker, who predicted their usefulness in medicine and surgery, it was decided that they should be called Roentgen rays. The sensational discovery was announced to the world on 6 January 1896, and was greeted with universal enthusiasm as one of the most dramatic events in the history of science.

Roentgen was awarded the Rumford Medal by the Royal Society of London in 1896 and the Nobel Prize in Physics in 1901. He was a member of more than 30 scientific societies. The fame resultant on his discovery, in such a simple, honest and truth-loving man, made him withdraw more and more into himself, and he became accessible only to his students and to visitors of "character, breeding and ability". With failing health, and saddened by the war and by the loss of his wife and friends, he retired from his chair at the University of Munich in 1920. He died in Munich from a gastrointestinal ailment on 10 February 1923.

Philatelically, Roentgen was honoured as a great physicist and Nobel Laureate by Danzig (now Gdansk in Poland), Suriname, both East and West Germany, Sweden, Spain and Togo.

AMA Gazette 1977; Sep.

\section{Rodolfo Robles (1878-1939)}

BORN IN 1878 in Guatemala, Rodolfo Robles studied medicine in Paris. After graduating in 1900 he became an outstanding and versatile physician and scientist.

He spoke many languages, and after repeated trips to Europe for postgraduate work, he became physician-in-chief of the gynaecological service of the General Hospital of Guatemala City. In 1916 he became professor of anatomy at the University of Guatemala.

Observing that many people were blind for unknown reasons, he traced the cause to the nematode Onchocerca volvulus. He called the disease pseudoleprosy and described it in detail in 1917 as onchocercosis; today it is known as onchocerciasis, river blindness or Robles disease.

He remained medically and scientifically active until his death on 8 November 1939 in Guatemala, leaving behind an international reputation. The highest medical honour in Guatemala carries his name.

Philatelically, he was honoured by Guatemala in 1963 and by Mexico on a World Health Organization stamp in 1974.

AMA Gazette 1976; May. 